bardziej irytujących trzeźwego archeologa, jak widzieć wiarę religijną mieszaną z magią przez propagatorów taniego materializmu. Dla każdego, kto wierzy w historyczną misję Palestyny - jej archeologia ma wartość, która wynosi ją wysoko ponad poziom wytworów czysto ludzkich, $z$ jakimi musi mieć ciągle do czynienia, w krainę gdzie historia i teologia dzielą tę samą wiarę $\mathrm{w}$ wieczne rzeczywstości egzystencji". KONIEC ORYGINAŁU ANGIELSKIEGO ${ }^{3}$.

Tyniec

O. LUDWIK S. MYCIELSKI OSB

S Str. 256.

Ks. Jerzy Chmiel

\title{
DEUTERO-IZAJASZ W NOWYM TESTAMENCIE. IV COLLOQUIUM BIBLIJNE W WIEDNIU
}

IV Colloquium biblijne $\mathrm{w}$ Wiedniu, które odbyło się $\mathrm{w}$ dniach $22-26$ X 1986 r., miało za temat: „Deutero-Izajasz i jego recepcja w Nowym. Testamencie". W Colloquium wzięli udział - obok egzegetów austriackich - bibliści z Polski, Węgier, Czechosłowacji i NRD. Z Polski przyjechało 11 biblistów, spośród których dwóch wygłosiło referaty. Można więc stwierdzić, że zwiększa się udział polskich biblistów na wiedeńskich spotkaniach (poprzednie były w latach: 1980, 1982, 1984 - zob. sprawozdania w RBL).

Referat wstępny - traktowany jako wykład gościnny w Uniwersytecie Wiedeńskim - wygłosił N. F üg lis ter (Salzburg) nt.: „Deutero-Izajasz jako ewangelia". A. Stigl ma ir (Brixen-Bressanone) przed.stawil sylwetke Sługi Jahweh w oparciu o wybrane teksty Iz 41-53. J. Marböck (Graz) mówił o zapowiedzi i wypełnieniu w adniesieniu do tematyki Exodus i Syjonu w Iz 52, 7-12; 62, 1-12. O recepcji Iz 42 w I It 12, 15-21 referował B. Tarjanyi (Budapeszt), a o interpretacji Iz $53,7-8 \mathrm{w} \mathrm{Dz} 8,32 \mathrm{n}-\mathrm{F}$. R o z man (Lubliana).

A oto dwa polskie wystąpienia.

Bp H. Muszyński (już obecnie ordynariusz włocławski) przedstawił referat pt. „Trzy sposoby przebaczenia według Deutero-Izajasza: ,już zapłacone", czyli odpokutowane (Iz 40,1-2); wolny dar Boży bez ludzkiej rekompensaty (Iz 43, 22-28) oraz poprzez zastępcze cierpienie i śmierć Sługi (Iz 53)". Każdy dział tematyczny był rozpatrywany z punktu widzenia tekstu oraz jego interpretacji.

H. L a ng k a mmer (KUL) rozprawiał nt. ,Iz 53 a 1 P 2, 21-25. O chrystologicznej interpretacji teologii cierpienia wg Iz 53". Referat został podzielony na 5 części: a) analiza 1 P 2, 21-25 z punktu widzenia historii form i tradycji; b) wypowiedzi dotyczące Ebed-Jahweh Iz 53 w 1 P 2, 21-25; c) Pieśń o męce w 1 P 2, 21-25 a przedstawienie pojednania w NT; d) Tytuł Ebed-Jahweh w NT i pieśń o męce w 1 P 2, $21-25$; e) pareneza o cierpieniu w 1 P 2, 18-25 i logika laski. Referat ten pt. Jes 53 und 1 Petr 2, 21-25. Zur christologischen Interpretation der 
Leidenstheologie von Jes 53 już się ukazal drukiem w „Bibel und Liturgie” 60,2 (1987) $90-98$.

Gospodarz i organizator Colloquium, J. K r e me r przy pomocy przeźroczy objaśnial tezy wyłożone w ostatniej swojej książce o Ėazarzu w referacie pt. „Wirkungsgeschichte jako klucz do wspólczesnego rozumienia J 11, 1-46" (zob. rec. książki Lazarus w RBL 1987, ss. 179n).

Dyskusje, jakie toczyły się po podstawowych referatach, a w których Polacy brali walny udział, dopełnialy całości tego pożytecznego spotkania naukowego.

Kraków

KS. JERZY CHMIEL

\section{Bp Julian Wojtkowski}

\section{COLLOQUIA MEDIAEVALIA 1987}

Polacy uczestniczący w „Sejmiku Mediewistów”, organizowanym przez Uniwersytet Koloński w latach parzystych, stwierdzili potrzebę podobnych spotkań krajowych w latach nieparzystych. Rada Naukowa Warmińskiego Instytutu Teologicznego Historyczno-Pastoralnego w Olsztynie podjęła inicjatywę, Biskup Administrator Apostolski Diecezji Warmińskiej Dr Edmund Piszcz objąl mecenat.

Pierwsze spotkanie odbyło się w Olsztynie 26 i 27 września 1987 roku. Wykłady i dyskusje dotyczyły źródeł i stanu badań nad początkami Kościoła i Państwa polskiego, nad polskim ustawodawstwem synodalnym, filozofią, wykładem Pisma świętego, kaznodziejstwem, duchowością, liturgią i językiem staropolskim.

Udział wzięli mediewiści z całej Polski: Gerard Labuda, Brygida Kurbis, Władysław Kuraszkiewicz, Zygmunt Zagórski i Wiesław Wydra z Poznania; Mieczysław Markowski, Zofia Włodek i Ks. Jerzy Wolny z Krakowa; Księża Wojciech Góralski, Stanisław Wielgus i Marek Zahajkiewicz z Lublina; Karol Górski z Torunia i Ks. Jerzy Pikulik z Warszawy. Olsztyn reprezentowali Biskupi Edmund Piszcz i Julian Wojtkowski oraz Ks. Marian Borzyszkowski, inicjator i organizator spotkania.

Dwudniowe obrady wykazały duże zasoby źródeł średniowiecznych, czekających na zbadanie mimo ogromnego wysiłku i wkładu pracy powojennej mediewistyki polskiej. Odczyty i dyskusje powinny ukazac się drukiem w „Studiach Warmińskich". Uczestnicy wysunęli szereg propozycji tematycznych na „Colloquia Mediaevalia 1989, które mają się odbyć na Warmii, w Olsztynie i w średniowiecznej kolegiacie Dobromiejskiej.

Olsztyn

BP JULIAN WOJTKOWSKI 